Research Article

\title{
cpDNA-Gene-Sequence-Based Genetic Diversity, Population Structure, and Gene Flow Analysis of Ethiopian Lowland Bamboo (Bambusinea: Oxytenanthera abyssinica (A. Rich.) Munro)
}

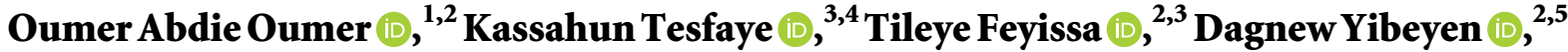 \\ Jayaraman Durai $\odot{ }^{6}{ }^{6}$ and Muhammad Zeeshan Hyder $\oplus^{7}$ \\ ${ }^{1}$ Assosa University (ASU), Assosa, Ethiopia \\ ${ }^{2}$ Addis Ababa University (AAU), Addis Ababa, Ethiopia \\ ${ }^{3}$ Institute of Biotechnology (IoB), Addis Ababa University (AAU), Addis Ababa, Ethiopia \\ ${ }^{4}$ Ethiopian Biotechnology Institute (EBTi), Ministry of Science and Technology (MoST), Addis Ababa, Ethiopia \\ ${ }^{5}$ Central Ethiopia Environment and Forest Research Centre (CE-EFRC), Addis Ababa, Ethiopia \\ ${ }^{6}$ International Network for Bamboo and Rattan (INBAR), Beijing, China \\ ${ }^{7}$ COMSATS University Islamabad (CUI), Park Road, Islamabad, Pakistan
}

Correspondence should be addressed to Oumer Abdie Oumer; oumer.abdie@aau.edu.et

Received 5 March 2021; Revised 27 April 2021; Accepted 7 June 2021; Published 16 June 2021

Academic Editor: Anna Źróbek-Sokolnik

Copyright (C) 2021 Oumer Abdie Oumer et al. This is an open access article distributed under the Creative Commons Attribution License, which permits unrestricted use, distribution, and reproduction in any medium, provided the original work is properly cited.

Background. As a member of Poaceae and subfamily Bambusoideae, Ethiopian lowland bamboo (Oxytenanthera abyssinica) is one of the most important nontimber forest resources or a potential alternative to wood and wood products. Ethiopia contributes $86 \%$ of the total area of bamboo on the continent, Africa, and 7\% of the world. O. abyssinica in Ethiopia accounts for $85 \%$ of the total national coverage of bamboo. Several studies have been performed on the genetic diversity and population structure analysis of various bamboo species throughout the world but almost nothing in Ethiopia and O. abyssinica. Methods. Young fresh leaves of O. abyssinica from thirteen natural lowland bamboo growing areas across the country were collected. DNA was isolated using a modified CTAB DNA isolation method. Three cpDNA gene sequences (matK, ndhF3, and rps16) were used for the study. PCR products were analyzed, purified, and pair-end sequenced to calculate AC/GC content, average number of nucleotide differences $(k)$, nucleotide diversity $(\pi)$ and population mutation rates per 100 sites $(\theta w)$, InDel (Insertion-Deletion), DNA divergence, gene flow, and genetic differentiation. Results. Metekel Zone was found to have extremely higher $k$, $\pi$, and $\theta w$. Higher frequency of genetic differentiation was found between Metekel Zone vs. the distant populations. Higher frequency of gene flow was found between Assosa Zone vs. Oromia populations. Kurmuk haplotype from gaps or missing data considered and Bambasi haplotype from not considered has descendants around them. Conclusion. Using sequences of cpDNA genes, populations of $O$. abyssinica collected in Ethiopia show clear diversity based on their geographic location. Metekel Zone was found to have the most diverse population, Assosa Zone has been found to be the source of evolution of O. abyssinica, and Gambella population shows a difference from other $O$. abyssinica populations.

\section{Introduction}

Bamboo is an arborescent perennial, giant, and woody grass belonging to order Poales (monocotyledon), family Poaceae (grass family), subfamily Bambusoideae, and tribe Bambuseae, encompassing $c a$. 1,662 species in 121 genera [1] and about 100 species are under commercial cultivation [2]. Bamboo is the fastest-growing plant, $100 \mathrm{~cm}$ per day, in the world [3] and one of the most important nontimber forest resources or a potential alternative to wood and wood products [4].

Bamboo is widely distributed in Asia, Latin America, and Africa from sea level to highlands in tropical, subtropical, 
and temperate countries $[5,6]$. According to the world bamboo resources assessment report, Ethiopia, Kenya, and Uganda possess most of the bamboo resources in Africa [7]. Ethiopia contributes to the leading coverage constituting more than 1.44 million hectares [8]. This constitutes about $86 \%$ of the total area of bamboo on the continent and $7 \%$ of the world [9].

There are two indigenous woody bamboo species in Ethiopia: the African Alpine Bamboo or highland bamboo (Yushania alpina K. Shumann Lin; synonym: Arundinaria alpina K. Schumann) and the monotypic genus lowland bamboo (Oxytenanthera abyssinica (A. Richard) Munro). These species occur in some other African countries, but nowhere other than the continent of Africa $[9,10]$. They are indigenous to Ethiopia and endemic to Africa, confined to the sub-Saharan region [9]. The lowland bamboo covers a range of elevation between 540 and $1750 \mathrm{~m}$ and highland bamboo at a higher elevation above 2,480 $\mathrm{m}$ [8]. The lowland bamboo (O. abysinica) in Ethiopia accounts for $85 \%$ of the total national coverage of bamboo, and the remaining $15 \%$ is covered by highland bamboo (A. alpina) $[9,11]$.

Genetic erosion of bamboo and their wild relatives are accelerating at a high rate because of human activities such as deforestation, wild firing, overexploitation, and introduction of exotic species without investigation and proper research on the potential impact of genetic pollution and general problems associated with transfer of exotic germplasm [1]. Ethiopia introduced around 23 new species of bamboo in two rounds since 2007. The first entries were by the Ministry of Agriculture and INBAR. Seven species of the 1 st entries have been tested for their adaptability and growth performance in different locations without adequate studies and inquiry. The second entries that comprise 16 species were introduced by Morel Agroindustries LTD. These species are under multiplication at Holetta and Gurd-shola nurseries of CE-EFRC, Addis Ababa [12].

As many as half of the world's woody bamboo species have become vulnerable to extinction as a result of massive forest destruction [13]. The most important problems currently faced by bamboos in Ethiopia are related with high abandonment of bamboo plant due to lack and/or gap of knowledge on its biology and genetics, presence of high genetic erosion, and destruction of the plant due to human activities (Grand Ethiopian Renaissance Dam (GERD) with a catchment area of $172,250 \mathrm{~km}^{2}$ [14] is built primarily on major lowland bamboo-growing areas of Metekel Zone of Benishangul, Gumuz Region (BGR)).

Relatively limited numbers of molecular finger printing studies have been carried out to assess the genetic diversity of bamboo species [2], and no genetic diversity study on O. abyssinica in Ethiopia has been conducted so far. The lack of research studies conducted in Ethiopia, especially on the diversity and systematics of $O$. abyssinica (the species with great ecological and industrial benefit and great coverage in Africa) at the DNA level, prompted the commencement of this research. Therefore, for the present study, we sequenced coding ( $m a t K$ and $n d h F$ ) and noncoding (rps16) regions of cpDNA genes aimed to assess the genetic diversity, population structure, and gene flow analysis of $O$. abyssinica collected from lowland bamboo-growing areas of the country.

\section{Materials and Methods}

2.1. Plant Material Collection. Young fresh leaves from thirteen natural $O$. abyssinica-growing areas across the country were collected. Representative young leaves (3-5) from three independent bamboos for each population were immersed and preserved in a $15 \mathrm{ml}$ falcon tube containing $2 \%$ CTAB $(2 \%$ CTAB, $100 \mathrm{mM}$ Tris-Base pH 8.0, $25 \mathrm{mM} \mathrm{Na}$-EDTA, $2 \mathrm{M}$ $\mathrm{NaCl}, 250 \mathrm{mg} / \mathrm{mL}$ PVP, and $2 \% \beta$-mercaptoethanol) solution. Areas of sample collection along with GPS data and altitudinal information are presented in Table 1. Maps showing sample coverage and collection site are described in Figure 1.

2.2. DNA Extraction and PCR Amplification. Genomic DNA from three independent samples of each sample was isolated using a modified CTAB method [15] at the Department of Biosciences, Laboratory of Biochemistry, Molecular Biology, and Biotechnology, COMSATS University, Islamabad, Pakistan. Leaves immersed in falcon tubes were taken out and crushed by using an autoclaved mortar and pestle using new fresh $1-2 \mathrm{ml}$ of $2 \%$ CTAB solution. Only $1 \mathrm{ml}$ of the crushed tissue was transferred to a new sterile centrifuge tube using blue pipette tips which were cut. Seven hundred microliter of chloroform was added to the crushed tissue and mixed thoroughly and centrifuged at $16000 \mathrm{~g}$ for 10 minutes $26^{\circ} \mathrm{C}$. Six hundred microliter of the supernatant (only clear mix) was transferred to the new fresh Eppendorf tube, and $60 \mu \mathrm{l}$ of $3 \mathrm{M}$ sodium acetate ( $\mathrm{pH}$ 5.2) was added and thoroughly mixed. Six hundred microliter of ice-cold isopropanol was added and gently mixed by inverting the tubes $3-5$ times, and then, the tubes were placed in a refrigerator $\left(-20^{\circ} \mathrm{C}\right)$ for $2 \mathrm{~h}$. The mix was centrifuged at $16000 \mathrm{~g}$ at $4^{\circ} \mathrm{C}$ for $5 \mathrm{~min}$ to precipitate the DNA. The supernatant was discarded, and the DNA was washed by $1 \mathrm{ml} 70 \%$ ethanol by dissolving the pallet completely in the wash buffer and centrifuged at $16000 \times g$ for $3 \mathrm{~min}$. at $4^{\circ} \mathrm{C}$. The wash step was repeated by cold absolute ethanol $(1 \mathrm{ml})$, and the pellet was air-dried. The pellet was dissolved in $60 \mu \mathrm{l} 0.1 \mathrm{X}$ TE (10 mM Tris-HCl pH 8.0 and $1 \mathrm{mM}$ EDTA pH 8.0) buffer containing RNase. Test gel electrophoresis in $1 \%$ agarose $(0.5 \mathrm{x}$ TBE buffer was used for gel preparation and run) and nanodrop (Implen Nanophotometer 190-1100 nm spectrophotometer) of each sample were measured, and those with high DNA quality were used for PCR amplification. Among ten primers that amplify ten specific cpDNA regions selected from $[16,17]$ and designed via Primer3 primer designing program (http://bioinfo.ut.ee/primer3-0.4.0/), three chloroplast sequences with coding ( $m a t K$ and $n d h F$ ) and noncoding (rps16 intron) were used (Table 2).

2.3. PCR Product Profiling, Sequencing, and Alignment. PCR reaction ( $50 \mu \mathrm{l}$ per reaction) and amplification contained $7.50 \mu \mathrm{l}$ of $50-100 \mathrm{ng} / \mu \mathrm{l}$ template DNA, $5.0 \mu \mathrm{l}$ of Taq buffer $\left(100 \mathrm{mM}\right.$ Tris- $\mathrm{HCl}, 500 \mathrm{mM} \mathrm{KCl}, 15 \mathrm{mM} \mathrm{MgCl}_{2}, \mathrm{pH}$ $8.5\left(25^{\circ} \mathrm{C}\right), 5.0 \mu \mathrm{l}$ of dNTPs mix $(2.5 \mathrm{mM}$ each), and $2.5 \mu \mathrm{l}$ of Taq DNA Polymerase $(5 \mathrm{U} / \mu \mathrm{l}) \quad\left(\mathrm{WizPure}^{\mathrm{TM}}\right.$ Taq DNA 
TABLE 1: Sample information along the GPS location.

\begin{tabular}{|c|c|c|c|c|c|c|}
\hline \multirow{2}{*}{ Region } & \multirow{2}{*}{ Zone } & \multirow{2}{*}{ District } & \multirow{2}{*}{ Specific collection site } & \multicolumn{2}{|c|}{ GPS reading } & \multirow{2}{*}{ Altitude a.s.l (m) } \\
\hline & & & & East & North & \\
\hline \multirow{9}{*}{ Benishangul-Gumuz } & \multirow{4}{*}{ Metekel } & Guba & Yarenja & $11^{\circ} 16^{\prime} 13.1^{\prime \prime}$ & $035^{\circ} 22^{\prime} 15.4^{\prime \prime}$ & 824 \\
\hline & & Dangur & Misreta & $11^{\circ} 18^{\prime} 50.3^{\prime \prime}$ & $036^{\circ} 14^{\prime} 10.6^{\prime \prime}$ & 1240 \\
\hline & & Mandura & Etsitsa & $11^{\circ} 09^{\prime} 14.5^{\prime \prime}$ & $036^{\circ} 19^{\prime} 50.3^{\prime \prime}$ & 1039 \\
\hline & & Pawe/Almu & Mender 30 & $11^{\circ} 18^{\prime} 32.5^{\prime \prime}$ & $036^{\circ} 24^{\prime} 40.2^{\prime \prime}$ & 1118 \\
\hline & \multirow{3}{*}{ Assosa } & Bambasi & Ambesa Chaka & $09^{\circ} 53^{\prime} 55.0^{\prime \prime}$ & $034^{\circ} 40^{\prime} 01.8^{\prime \prime}$ & 1518 \\
\hline & & Assosa & Tsetse Adurnunu & $10^{\circ} 09^{\prime} 29.9^{\prime \prime}$ & $034^{\circ} 31^{\prime} 37.1^{\prime \prime}$ & 1507 \\
\hline & & Kurmuk & HorAzab & $10^{\circ} 32^{\prime} 33.7^{\prime \prime}$ & $034^{\circ} 28^{\prime} 57.9^{\prime \prime}$ & 1275 \\
\hline & \multirow{2}{*}{ Kemash } & Kemash & Kemash & $09^{\circ} 29^{\prime} 31.4^{\prime \prime}$ & $035^{\circ} 52^{\prime} 35.2^{\prime \prime}$ & 1234 \\
\hline & & Yasso & Dangacho & $09^{\circ} 52^{\prime} 27.5^{\prime \prime}$ & $036^{\circ} 05^{\prime} 32.6^{\prime \prime}$ & 1176 \\
\hline \multirow{2}{*}{ Oromia } & West Wollega & Gimbi & Aba Sena Forest & $09^{\circ} 01^{\prime} 32.2^{\prime \prime}$ & $035^{\circ} 59^{\prime} 54.1^{\prime \prime}$ & 1407 \\
\hline & Buno Bedele & Dabu Hena & Didhessa Valley & $08^{\circ} 40^{\prime} 21.1^{\prime \prime}$ & $036^{\circ} 23^{\prime} 32.9^{\prime \prime}$ & 1399 \\
\hline Gambella & Gambella & Abol & Penkwe & $08^{\circ} 14^{\prime} 13.1^{\prime \prime}$ & $034^{\circ} 31^{\prime} 06.2^{\prime \prime}$ & 435 \\
\hline SNNPs & Konta & Konta & Koyshe & $06^{\circ} 43^{\prime} 35.6^{\prime \prime}$ & $036^{\circ} 34^{\prime} 26.8^{\prime \prime}$ & 958 \\
\hline
\end{tabular}

Polymerase)), $1.25 \mu \mathrm{l}$ of $25 \mathrm{pM}$ of each primer (Table 2), and $28.75 \mu \mathrm{l}$ of PCR grade $\mathrm{H}_{2} \mathrm{O}$. Profile of PCR for all primer sets included pre-PCR denaturation at $96^{\circ} \mathrm{C}$ for $3 \mathrm{~min}$ followed by 35 cycles of denaturing at $96^{\circ} \mathrm{C}$ for $30 \mathrm{sec}$., annealing at $53^{\circ} \mathrm{C}$ for $30 \mathrm{sec}$., extension at $72^{\circ} \mathrm{C}$ for $1 \mathrm{~min}$., a final extension at $72^{\circ} \mathrm{C}$ for $20 \mathrm{~min}$, and hold at $4^{\circ} \mathrm{C}$. $3.0 \mu \mathrm{l} \mathrm{PCR}$ products were analyzed using a standard $1 \%$ agarose gel electrophoresis and purified and paired-end sequenced at Macrogen, Inc. Seoul, Korea.

The sequence of both strands of every fragment amplified from each sample was assembled separately using DNA Dragon version 1.6.0, and each sampling district was represented by a single sequence with the one very identical and informative among the triplicate samples. BLAST searches for each target sequence were used to confirm probable homology (query cover, identity percentage, $E$-value, and direction of the strand). The assembled sample sequence was then submitted to the GenBank and used for sequence analysis. Sequences of three markers from each samples were arranged in FASTA format and aligned in MAFFT (multiple sequence alignment software version 7) [18] and realigned again using MUSCLE (multiple sequence comparison by log-expectation) of MEGA $\mathrm{X}$ [19] to increase the quality of final alignment product. Sequence information for submission to NCBI was prepared by Sequin v5.51. An accurate and complete GenBank record or accession number is reported in Table 3.

2.4. Evolutionary Tree Construction and Network Analysis. The sequence alignments with MUSCLE were used to identify the best nucleotide substitution model and construct the neighbor-joining (NJ) tree (Figure 2) using MEGA version 7.0. The NJ tree analysis was conducted using Kimura's two-parameter distance correction mode to build a phylogenetic tree. The evolutionary distances were calculated based on the Maximum Composite Likelihood (MCL) method [20] and are in the units of the number of base substitutions per site. Gamma distribution (shape parameter $=1$ ) was used for the rate variation among sites. For each sequence pair, all ambiguous positions have been removed, and for the final dataset, there were a total of 3,694 positions. DnaSP version 6.10.01 was used to generate haplotype files (with and without the use of the indels) for network analysis. The generated sequence files were saved as a Roehl format, and network analyses were performed via Network version 5.0.1.1 (http://www.fluxus-engineering.com/sharenet.htm).

2.5. Nucleotide Diversity, InDel Polymorphism, and Gene Flow and Genetic Differentiation. DnaSP version 6.10.01 was used to calculate and analyze (1) nucleotide diversity including an average number of nucleotide difference $(k)$, nucleotide diversity $(\pi)$, and population mutation rates per 100 sites $(\theta w)$ for total sequence (coding + noncoding regions together) and coding and noncoding regions separately, (2) InDel polymorphism including the number of sites with fixed gaps, total number of (InDel and non-InDel) sites, average InDel length, InDel diversity $k(i)$, and InDel diversity per sites $\pi(i)$, and (3) gene flow and genetic differentiation including gene flow via genetic differences among population (Gamma St) and average level of gene flow (Fst) and genetic differentiation via nucleotide-sequence-based statistics (Ks) and average number of nucleotide differences between population 1 and population 2 (Kxy).

\section{Results and Discussion}

There were 13 nucleotide sequences involved in the analysis of the current study. For each pair of sequences, each ambiguous position was removed, and in the last dataset, there was an aggregate of 3,694 positions. Evolutionary history using NJ together with nucleotide diversity analysis, DNA divergence between populations, InDel polymorphism, and gene flow and genetic differentiation analysis on $O$. abyssinica was investigated to analyze on this paper which is the first to study the plants genetic diversity, population structure, and gene flow using coding (matK and $n d h F$ ) and noncoding (rps16) regions of cpDNA genes.

\subsection{Chloroplast DNA Sequence Character and Sequence Divergence}

3.1.1. GC and AT Content Analysis. The highest AT content $(66.6 \%)$ in Bambasi, Kurmuk, and Pawe populations and 


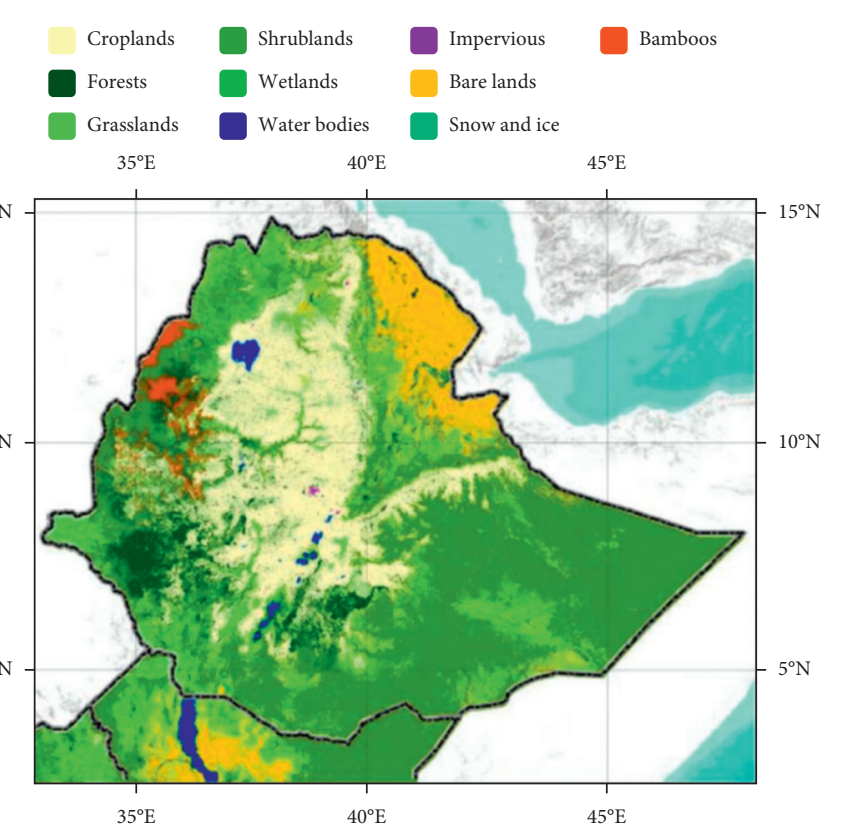

(a)

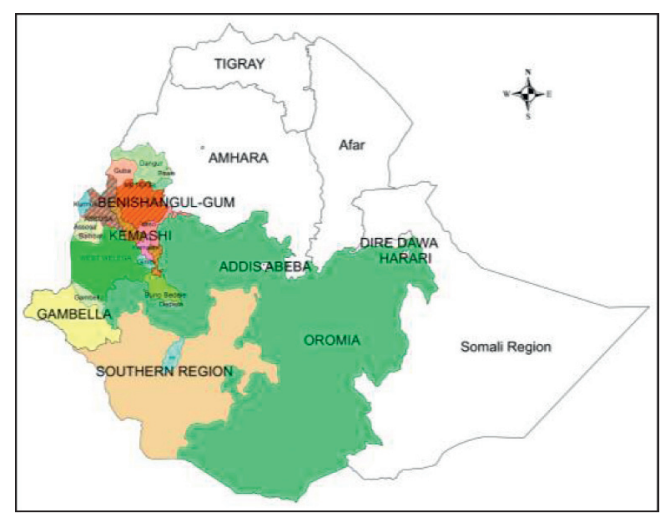

(b)

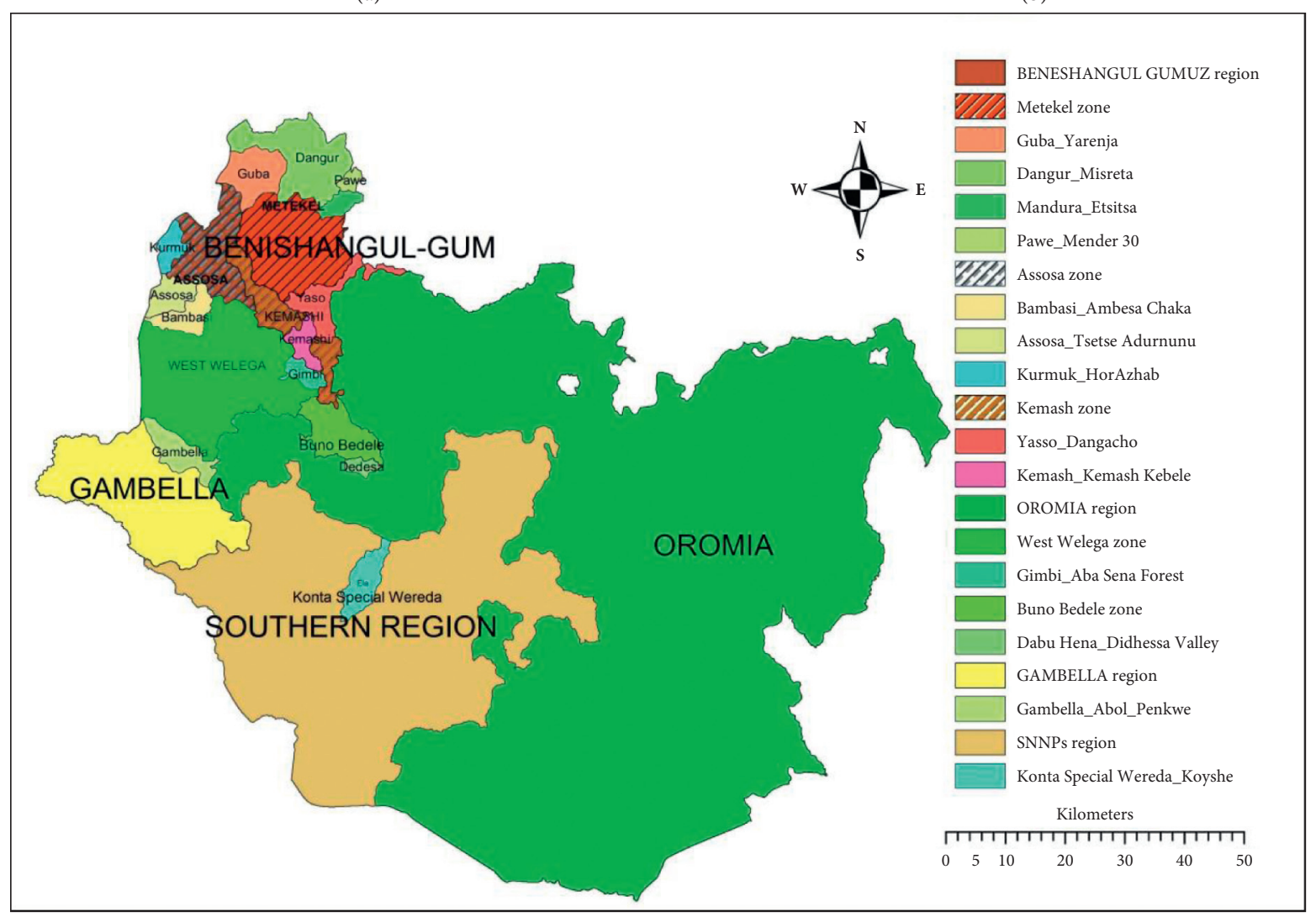

(c)

FIGURE 1: Maps showing the sample collection area. (a) Ethiopia's bamboo cover map in the Finer Resolution Observation and MonitoringGlobal Land Cover (FROM-GLC) classification scheme with other land cover classes, (b) map of Ethiopia showing the sample collection area, and (c) clipped map showing the sample collection area.

the least (66.4\%) in Dangur, Abol, and Dabu Hena populations were observed by the aggregate genes, while the GC content was the highest (33.6\%) in Dangur, Abol, and Dabu Hena populations and the least (33.4\%) was observed in Bambasi, Kurmuk, and Pawe populations
(Table 4). Average GC and AT content and total sequence were $66.5 \%, 33.5 \%$, and 3658.6 , respectively, in the aggregate cpDNA genes. Since the comparison was between different populations of a single species (O. abyssinica), there was no significant difference on GC and AT content 
TABLE 2: cpDNA primer sequences, their approximate amplified size, and PCR profile.

\begin{tabular}{|c|c|c|c|c|}
\hline $\begin{array}{l}\text { Primer } \\
\text { name }\end{array}$ & $\begin{array}{l}\text { Amplified size } \\
\text { (bp) }\end{array}$ & Primer sets & $\begin{array}{l}\text { Amplification } \\
\text { pattern }\end{array}$ & PCR profile (all end with $4^{\circ} \mathrm{C}$ hold) \\
\hline matK & $\sim 1,350$ & $\begin{array}{l}\text { F: CGTTCTGACCATATTGCACTATG } \\
\text { R: AACTAGTCGGATGGAGTAG }\end{array}$ & Excellent & \\
\hline$n d h F$ & $\sim 1,140$ & $\begin{array}{c}\text { F: GTCTCAATTGGGTTATATGATG } \\
\text { R: } \\
\text { CCCСCTAYATATTTGATACCTTCTCC }\end{array}$ & Excellent & $\begin{array}{c}96^{\circ} \mathrm{C}, 3 \mathrm{~min} . ; 35 \mathrm{X}\left(96^{\circ} \mathrm{C}, 30 \mathrm{sec} ., 53,30 \mathrm{sec} .\right. \\
\left.72^{\circ} \mathrm{C} 1 \mathrm{~min} .\right) ; 72^{\circ} \mathrm{C}, 20 \mathrm{~min}\end{array}$ \\
\hline rps 16 & $\sim 860$ & $\begin{array}{l}\text { F: AAACGATGTGGTARAAAGCAAC } \\
\text { R: AACATCWATTGCAASGATTCGATA }\end{array}$ & Excellent & \\
\hline
\end{tabular}

Table 3: An accurate and complete GenBank record (accession numbers at the NCBI).

\begin{tabular}{|c|c|c|c|}
\hline \multirow{2}{*}{ Sample name } & \multicolumn{2}{|c|}{ Coding region } & \multirow{2}{*}{$\begin{array}{c}\text { Intron } \\
\text { rps16 }\end{array}$} \\
\hline & matK & ndhF & \\
\hline Bambasi & MH445413 & MH445426 & MH445439 \\
\hline Assosa & MH445414 & MH445427 & MH445440 \\
\hline Kurmuk & MH445415 & MH445428 & MH445441 \\
\hline Guba & MH445416 & MH445429 & MH445442 \\
\hline Dangur & MH445417 & MH445430 & MH445443 \\
\hline Mandura & MH445418 & MH445431 & MH445444 \\
\hline Pawe & MH445419 & MH445432 & MH445445 \\
\hline Kemash & MH445420 & MH445433 & MH445446 \\
\hline Yasso & MH445421 & MH445434 & MH445447 \\
\hline Gimbi & MH445422 & MH445435 & MH445448 \\
\hline Dedhesa & MH445423 & MH445436 & MH445449 \\
\hline Abol & MH445424 & MH445437 & MH445450 \\
\hline Koyshe & MH445425 & MH445438 & MH445451 \\
\hline
\end{tabular}

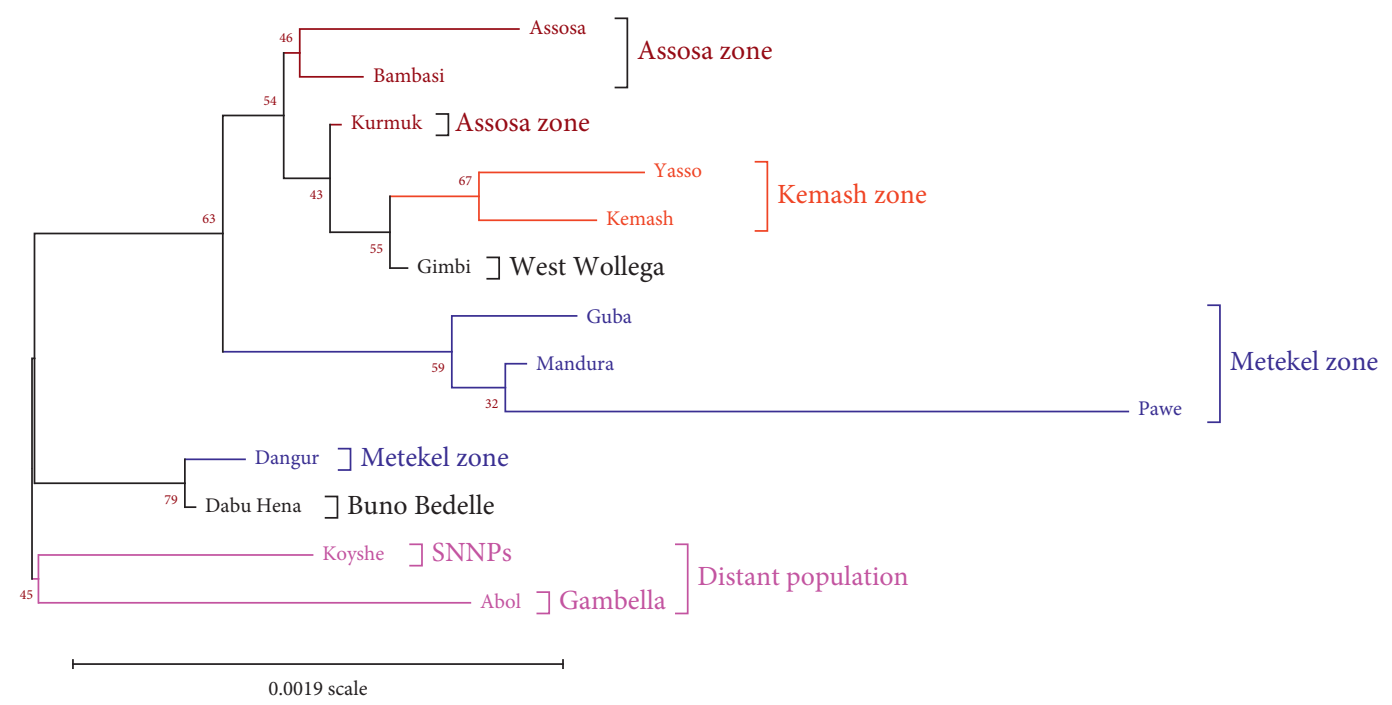

FIGURE 2: The neighbor-joining tree of $O$. abyssinica obtained based on pair-wise distance from the combined data of matK, ndhF, and rps16.

observed and the result of each samples was close to the average.

3.1.2. Neighbor-Joining Method Evolutionary History of Ethiopian Lowland Bamboo. The evolutionary history of bamboo was inferred based on the Neighbor-Joining [21] method. NJ shows the optimal tree with the total length of the branch $=0.01179101$ (Figure 2). Except samples collected from the Oromia Region that show mixing with Kemash and Metekel groups, other populations form their own group which secures the distinctness of their population and effectiveness of genes used for the study.

Three major clusters and three subclusters with five clades (Assosa Zone, Kemash Zone, Metekel Zone, the distant, and the intermixed Oromia Region samples) were formed in the final NJ analysis. The three cpDNA genes (matK, ndhF $3^{\prime}$, and rps16) were analyzed separately and then combined into a single data to 
TABLE 4: GC and AT content of each aggregate cpDNA genes.

\begin{tabular}{|c|c|c|c|c|c|c|c|c|c|c|c|c|}
\hline \multirow{3}{*}{ Sample name } & \multicolumn{3}{|c|}{ matK ( 1,350 bp) } & \multicolumn{3}{|c|}{ ndhF ( 1,140 bp) } & \multicolumn{3}{|c|}{ rps16 ( 860 bp) } & \multicolumn{3}{|c|}{ Aggregate genes } \\
\hline & \multicolumn{2}{|c|}{ Percentage } & \multirow{2}{*}{ Total sequence } & \multicolumn{2}{|c|}{ Percentage } & \multirow{2}{*}{ Total sequence } & \multicolumn{2}{|c|}{ Percentage } & \multirow{2}{*}{ Total sequence } & \multicolumn{2}{|c|}{ Percentage } & \multirow{2}{*}{ Total sequence } \\
\hline & AT & GC & & AT & GC & & AT & GC & & AT & GC & \\
\hline Assosa & 66.4 & 33.6 & 1778.0 & 66.8 & 33.2 & 1057.0 & 65.9 & 34.1 & 848.0 & 66.5 & 33.5 & 3670.0 \\
\hline Bambasi & 66.4 & 33.6 & 1778.0 & 66.7 & 33.3 & 1057.0 & 66.0 & 34.0 & 853.0 & 66.6 & 33.4 & 3666.0 \\
\hline Kurmuk & 66.4 & 33.6 & 1778.0 & 66.8 & 33.2 & 1057.0 & 66.2 & 33.8 & 852.0 & 66.6 & 33.4 & 3669.0 \\
\hline Kemash & 66.4 & 33.6 & 1778.0 & 66.6 & 33.4 & 1057.0 & 66.2 & 33.8 & 852.0 & 66.5 & 33.5 & 3662.0 \\
\hline Yasso & 66.4 & 33.6 & 1778.0 & 66.6 & 33.4 & 1057.0 & 66.2 & 33.8 & 852.0 & 66.5 & 33.5 & 3656.0 \\
\hline Dangur & 66.4 & 33.6 & 1779.0 & 66.4 & 33.6 & 1057.0 & 66.1 & 33.9 & 852.0 & 66.4 & 33.6 & 3680.0 \\
\hline Guba & 66.4 & 33.6 & 1778.0 & 66.7 & 33.3 & 1056.0 & 66.2 & 33.8 & 852.0 & 66.5 & 33.5 & 3634.0 \\
\hline Mandura & 66.4 & 33.6 & 1779.0 & 66.6 & 33.4 & 1056.0 & 66.2 & 33.8 & 852.0 & 66.5 & 33.5 & 3635.0 \\
\hline Pawe & 66.4 & 33.6 & 1779.0 & 66.4 & 33.6 & 1057.0 & 66.1 & 33.9 & 852.0 & 66.6 & 33.4 & 3648.0 \\
\hline Abol & 66.4 & 33.6 & 1778.0 & 66.5 & 33.5 & 1058.0 & 66.0 & 34.0 & 852.0 & 66.4 & 33.6 & 3671.0 \\
\hline Gimbi & 66.3 & 33.7 & 1779.0 & 66.8 & 33.2 & 1057.0 & 66.2 & 33.8 & 852.0 & 66.5 & 33.5 & 3648.0 \\
\hline Dabu Hena & 66.4 & 33.6 & 1779.0 & 66.4 & 33.6 & 1057.0 & 66.1 & 33.9 & 852.0 & 66.4 & 33.6 & 3650.0 \\
\hline Koyshe & 66.5 & 33.5 & 1778.0 & 66.4 & 33.6 & 1057.0 & 66.1 & 33.9 & 853.0 & 66.5 & 33.5 & 3673.0 \\
\hline Average & 66.4 & 33.6 & 1778.4 & 66.6 & 33.4 & 1056.9 & 66.1 & 33.9 & 851.8 & 66.5 & 33.5 & 3658.6 \\
\hline
\end{tabular}

construct an optimal NJ tree (Figures 3(a)-3(d)). All positions with gaps and missing data were removed. There was a total of $(A)=1,771,(B)=1001,(C)=834$, and $(D)=2,773$ positions in the final dataset. The sum of branch length $(A)=0.00339115$, $(B)=0.01103842,(C)=0.00780990$, and $(D)=0.00668883$ was obtained. The percentage of replicate trees clustered together in the bootstrap test [22] by the associated taxa 1000 replicates is shown next to the branches. With branch lengths in the same units as those of the evolutionary distances used to construct the phylogenetic tree, the tree is drawn to scale. Evolutionary distances were calculated using the MCL method and are in the number of base substitutions per site units. The $n d h F 3^{\prime}$ gene of the cpDNA alone shows the result similar with all primers merged together. In all conditions, samples collected from Kemash Zone were not separated and always together with great nodal support, and this population showed to be lastly evolved except for Figure 3(b).

3.2. Network Analysis. The total number of mutations disregarding the torso $(130,27)$, estimated number of mutations of shortest tree within the torso $(73,0)$, estimated number of mutations of shortest tree $(203,27)$, total number of taxa $(13,13)$, and total number of haplotypes $(13$, 11) were observed on gaps considered and not considered network analysis. Number values before parenthesis are for gaps considered and after parenthesis are for gaps not considered. Haplotype 8 (Kurmuk sample of Assosa Zone) from gaps considered (Figure 4(a)) and haplotype 2 (Bambasi sample of Assosa Zone) from gaps not considered (Figure 4(b)) have descendants around them, many of which differ from them by nucleotide change (at sites shown by numbers), and some are more distantly related. Both forms approve that Assosa Zone is the root of $O$. abysinica and others have diverged from this zone. The distant populations H_3 (Abol sample of Gambella Region) and H_11 (Koyshe sample of SNNPs Region) from gaps not considered and H_3 (Abol sample of Gambella Region) and H_13 (Koyshe sample of SNNPs Region) from gaps considered showed to be distant from the root.
3.3. Nucleotide Diversity Analysis. Metekel Zone found extremely higher $k(23.17), \pi(0.00633 \pm 0.00046)$, and $\theta w$ (22.33333 \pm 0.00099$)$. Distant populations (11.000, $0.00300 \pm 0.00150$, and $11.00000 \pm 0.00222$ ) followed by Oromia, Assosa Zone, and Kemash Zone were found to be lower in $k, \pi$, and $\theta w$ (Table 5). This implicates that gene differentiation in Metekel Zone and the distant populations is higher and that makes them a diverse population as compared to others.

3.4. InDel Polymorphism Analysis. The average InDel length was higher on Kemash (15.33) and Metekel Zones (12.21), and the lower value was observed on Assosa (7.14), distant, and Oromia populations (Figure 5), whereas the total number of (InDel and non-InDel) sites analyzed were higher for populations of Metekel $(3,692)$, distant population $(3,679)$, and Assosa Zone $(3,678)$, but Oromia and Kemash Zone populations show a relatively smaller value (Figure 5). Higher frequency of InDel makes Metekel, the distant population, and Assosa Zone populations more diverse than Oromia $(3,654)$ and Kemash Zone $(3,668)$ populations. From this, we can conclude InDel plays a significant role in genetic differentiation and population structure of O. abysinica populations.

3.5. Analysis of DNA Divergence. DNA divergence between populations was higher between populations of Metekel, Oromia, Kemash, and Assosa Zone vs. distant populations in chronological order (Figure 6). The $k$ was higher between Metekel Zone vs. distant population (9.5) followed by Oromia vs. distant population (8.67) and Kemash Zone vs. distant population (8.47). The least $k$ was found between populations of Assosa vs. Kemash Zone and between Assosa Zone vs. Oromia. The $\pi(t)$ was higher between Metekel Zone vs. distant population (0.0026) followed by Oromia vs. distant population (0.0024) and Kemash Zone vs. distant population $(0.0023)$. The least $\pi(t)$ was found between 


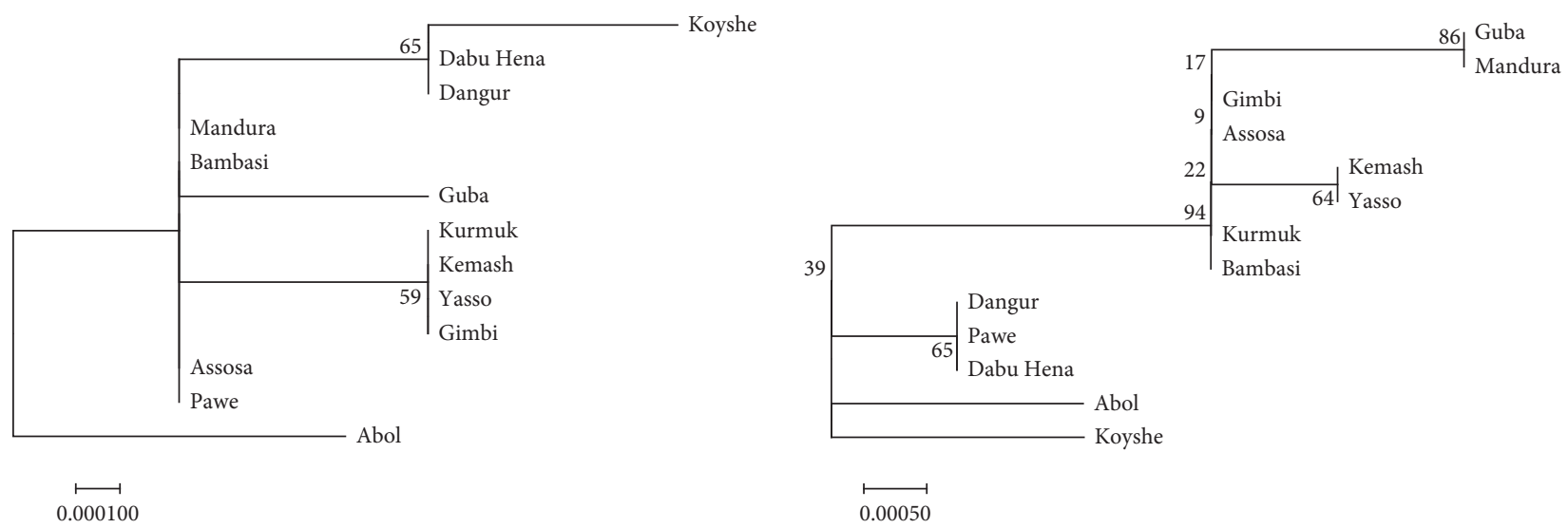

(a)

(b)

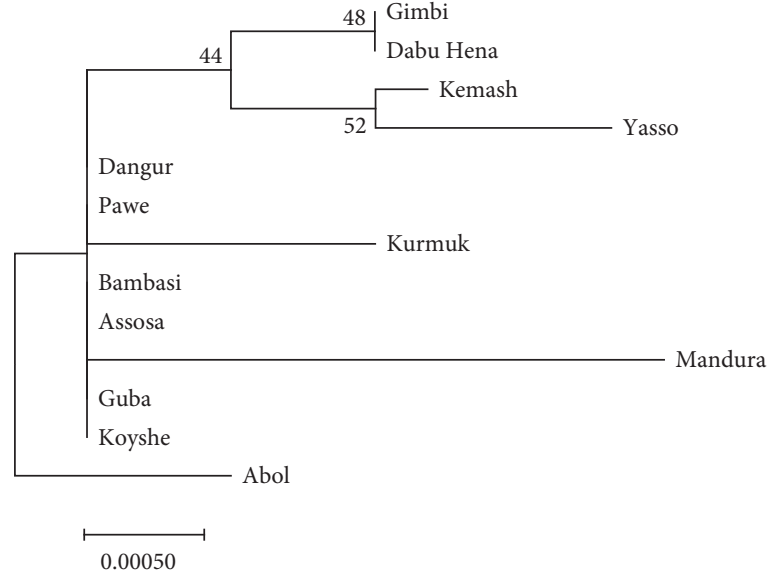

(c)

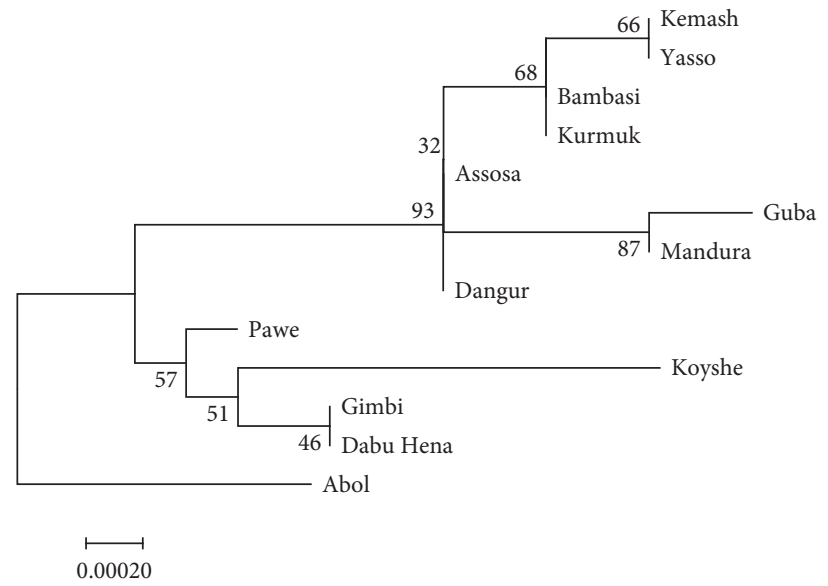

(d)

FIgURE 3: The NJ tree obtained based on pair-wise distance from individual and merged primers on 13 Ethiopian lowland bamboo populations. (a) $m a t K$, (b) $n d h F 3^{\prime}$, (c) rps16, and (d) $m a t K+n d h F 3^{\prime}$ end.

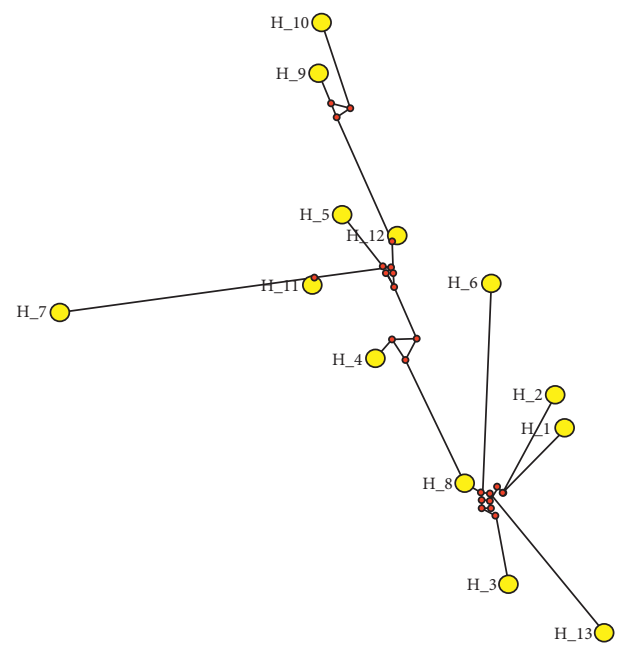

(a)

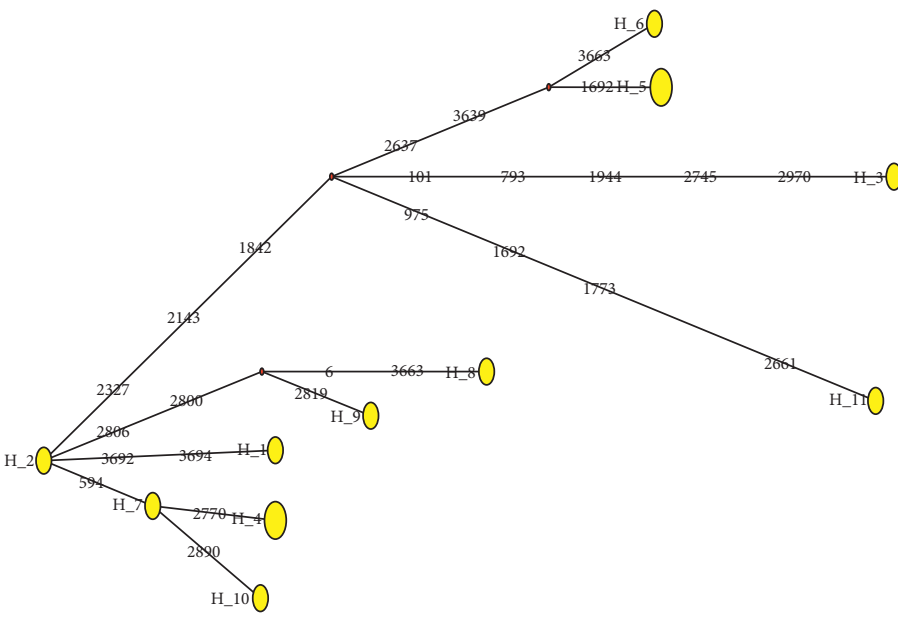

(b)

Figure 4: Network obtained based on (a) gaps/missing data considered and (b) gaps/missing data not considered. Note 1: haplotypes for (a): H_1 [Assosa], H_2 [Bambasi], H_3 [Abol], H_4 [Kemash], H_5 [Yasso], H_6 [Dangur], H_7 [Pawe], H_8 [Kurmuk], H_9 [Guba], H_10 [Guba], H_11 [Mandura], H_12 [Dabu Hena], and H_13 [Gimbi]. Note 2: haplotypes for (b): H_1 [Assosa], H_2 [Bambasi], H_3 [Äbol], H_4 [Kemash + Yasso], H_5 [Dangur + Dabu Hena], H_6 [Pawe], H_7 [Kurmuk], H_8 [Guba], H_9 [Mandura], H_10 [Gimbi], and H_11 [Koyshe]. 
TABle 5: Nucleotide diversity analysis on O. abyssinica populations in different zones.

\begin{tabular}{|c|c|c|c|c|c|c|c|c|c|}
\hline \multicolumn{10}{|c|}{ Analysis in pair-wise comparisons } \\
\hline \multirow{2}{*}{ Population } & \multicolumn{3}{|c|}{ Total } & \multicolumn{3}{|c|}{ Coding region } & \multicolumn{3}{|c|}{ Noncoding region } \\
\hline & $k$ & $\pi$ & $\theta w$ & $k$ & $\pi$ & $\theta w$ & $k$ & $\pi$ & $\theta w$ \\
\hline Assosa Zone & 4.33 & $0.0012 \pm 0.0003$ & $4.33 \pm 0.0006$ & 2.00 & $0.0007 \pm 0.0002$ & $2.00 \pm 0.0005$ & 1.33 & $0.0016 \pm 0.0007$ & $1.33 \pm 0.0013$ \\
\hline Metekel Zone & 23.17 & $.0063 \pm 0.0005$ & $22.33 \pm 0.0$ & 10.67 & $0.0038 \pm 0.00$ & $10.12 \pm 0.001$ & 1.33 & $0.0016 \pm 0.0003$ & $1.09 \pm 0.0010$ \\
\hline Kemash Zone & 2.00 & $0.0005 \pm 0.0003$ & $2.00 \pm 0.0005$ & 0 & $0 \pm 0$ & $0 \pm 0$ & 0 & $0 \pm 0$ & $0 \pm 0$ \\
\hline Oromia & 8.00 & $0.0022 \pm 0.0011$ & $8.00 \pm 0.0016$ & 6.00 & $0.0021 \pm 0.0011$ & $6.00 \pm 0.0016$ & 2.00 & $0.0023 \pm 0.0012$ & $2.00 \pm 0.0020$ \\
\hline Distant pop. & 11.00 & $0.0030 \pm 0.0015$ & $11.0 \pm 0.0022$ & 8.00 & $0.0028 \pm 0.0014$ & $8.00 \pm 0.0021$ & 2.00 & $0.0023 \pm 0.0012$ & $2.00 \pm 0.0020$ \\
\hline
\end{tabular}

Note. $k$ denotes average number of nucleotide differences, $\pi(\mathrm{Pi})$ : pair-wise average nucleotide diversity per 100 sites along with standard deviation, and $\theta w$ (Theta- $w$ ) signifies the Watterson estimator for population mutation rates per 100 sites with its standard deviation.
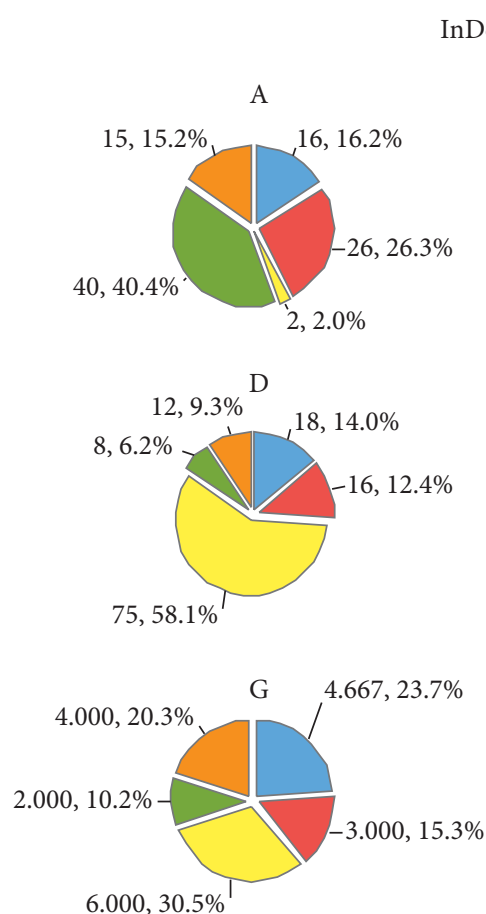

$6.000,30.5 \%$

InDel polymorphism of Ethiopian lowland bamboo (O. abyssinica) Frequency and percentage

B

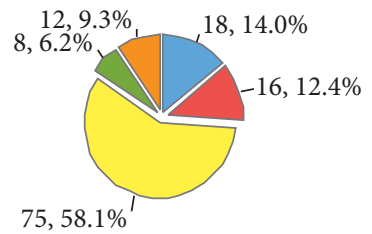

$\mathrm{E}$

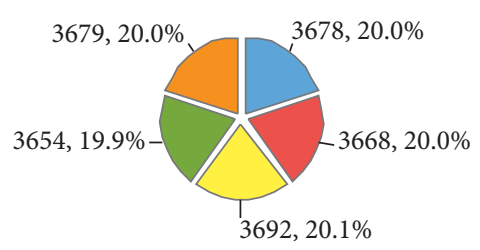

$\mathrm{H}$

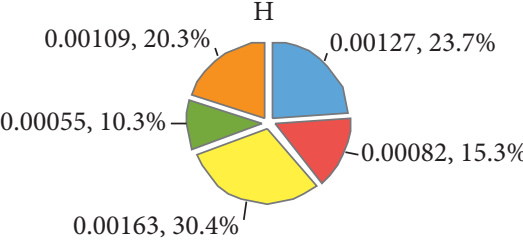

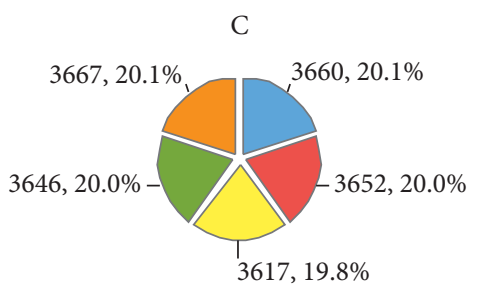

F

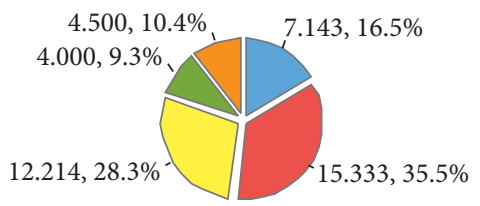

Where

$A=$ number of sites with fixed gaps

$\mathrm{B}=$ total number of InDel sites

$\mathrm{C}=$ total number of InDel sites analysed

$\mathrm{D}=$ total number of non-InDel sites analysed

$\mathrm{E}=$ total number of (InDel and non-InDel) sites analysed

$\mathrm{F}=$ average InDel length

$\mathrm{G}=$ InDel diversity, $k$ (i)

$\mathrm{H}=\mathrm{InDel}$ diversity per sites, $\pi$ (i)

\section{Category}

Assosa zone

Kemash zone

Metekel zone
Oromia

Out group

FIGURE 5: Frequency and percentage of InDel polymorphism of the O. abyssinica population in Ethiopia.

populations of Assosa Zone vs. Kemash Zone and between Assosa Zone vs. Oromia.

The MP in P1, but monomorphic in $\mathrm{P} 2$, was higher between Metekel Zone vs. distant population (10) followed by Oromia vs. distant population (7) and Metekel Zone vs. Oromia (5). The MP in P1, but monomorphic in P2, was found to be zero between populations of Kemash vs. Metekel Zone and between Kemash Zone vs. Oromia. The MP in P2, but monomorphic in P1, was higher between Assosa Zone vs. Metekel Zone (11) and between Kemash Zone vs. Metekel Zone (11) followed by Kemash Zone vs. the distant population (10). The least MP in P2, but monomorphic in P1, was found between populations of Metekel Zone vs. Oromia followed by between Assosa Zone vs. Kemash Zone. The $\pi$ between populations was higher between distant populations vs. Kemash Zone (11.5) followed by distant populations vs. Metekel Zone (9.5) and distant population vs. Assosa Zone (9.33). The least $\pi$ between populations was found between populations of Assosa Zone vs. Kemash Zone and between Assosa Zone vs. Oromia.

Any population compared to the distant populations was found to have larger DNA divergence than others. This tells us DNA of the distant population is distinctly different from that of other populations. DNA divergence between Assosa vs. Kemash Zone, Assosa vs. Oromia Zone, and Kemash Zone vs. Oromia was found to be smaller. Those three zones (Assosa, Kemash, and Oromia) are very close to each other, and there might be seed and/or seedling transfer between 

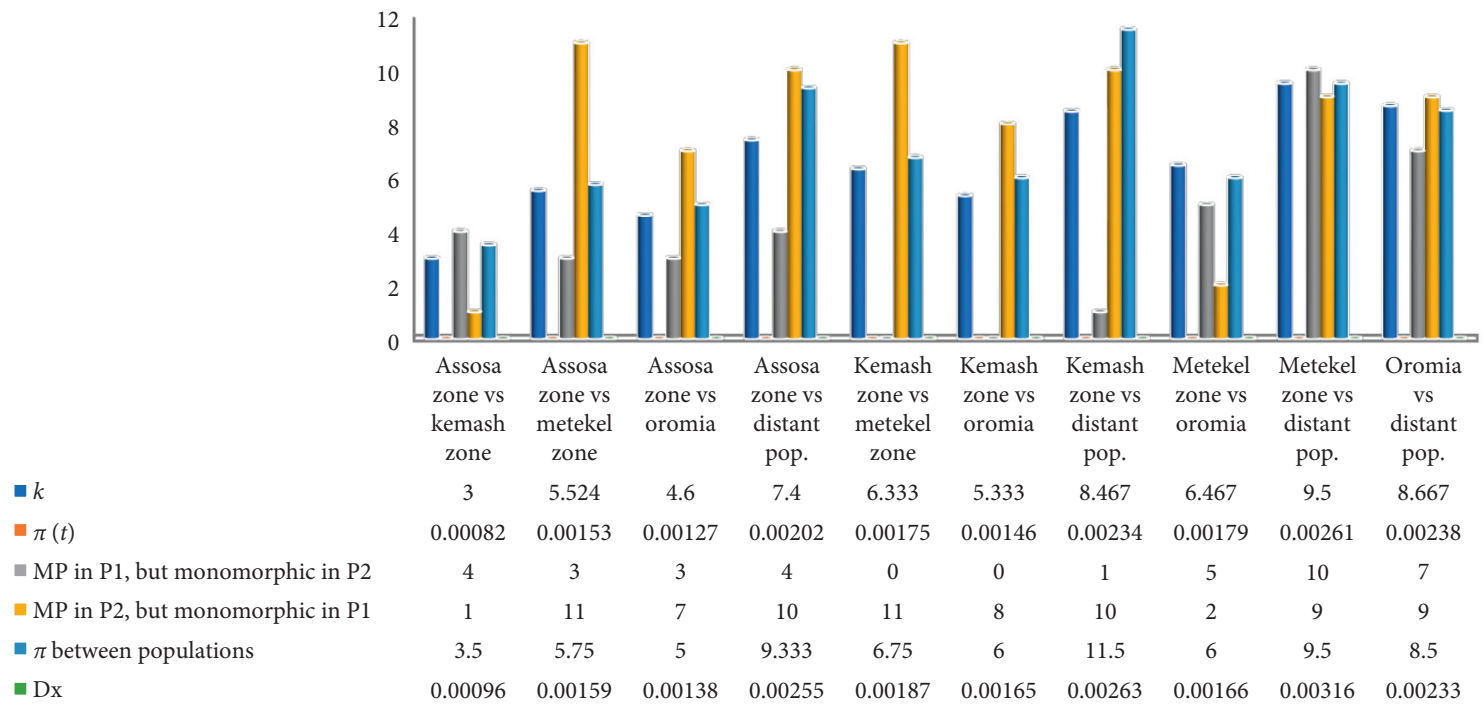

Figure 6: DNA divergence between different zones of $O$. abyssinica populations in Ethiopia. Note: $k$ denotes the average number of nucleotide differences, $\pi(t)$ : nucleotide diversity, MP: mutations polymorphic, P1: population 1, P2: population $2, \pi$ : average number of nucleotide differences, and Dx: average number of nucleotide substitution per site between populations.

populations that make them close and related to each other on their genetic makeup.

3.6. Gene Flow and Genetic Differentiation Analysis. Extremely higher frequency of genetic differentiation was found between Metekel Zone vs. the distant population (51.63) and between Assosa Zone vs. Metekel Zone (51.5). The least frequency was observed between Kemash Zone vs. Oromia (19.25) and between Assosa Zone vs. Oromia (23.0). Higher frequency of gene flow was found between Assosa Zone vs. Oromia (0.61) and between Kemash Zone vs. Oromia (0.51), and a minimum frequency of gene flow was observed between Metekel Zone vs. the distant population (0.023) and between Oromia vs. the distant populations (Table 6). This implicates that gene flow to Metekel Zone and the distant populations is rare and that makes diverse population as compared to others.

Genetic diversity is the basis for the ability of an organism to adapt to environmental changes and can be influenced by many factors [23]. Geographical factors (e.g., landscape, latitude, longitude, and altitude) and environmental factors (e.g., temperature and precipitation) influence the genetic diversity and population structure of a species and the individuals among populations [24, 25]. Biological factors such as mutation, genetic drift, mating system, pollination mode, gene flow, and selection also influence the diversity of the plant species and population [26]. Mainly, mutations within the DNA are the source of variations. InDels usually occur by reason of certain cellular mechanisms, including transposable elements movement, replication slippage, and crossing over imbalanced within genomes [27]. InDels are an essential phenomenon that can have a harmful or advantageous effect on specific genomes' loci $[28,29]$. InDels are one the main variation sources found within the genomes of various species of plants, including Arabidopsis [30], tomato [31, 32], rice [33], chickpea [34], moso bamboo [35], Sorghum species [36], and Gastrodia elata (Orchidaceae) [37]. InDels also used for identifying the genetic variants underlying phenotypic variation in plants without complete genomes [38]. Examination of DNA differences among closely related species or among polymorphic DNA variations of a species will provide insight into the mutation nature and evolution process [39]. InDel analysis on O. abyssinica also shows that gene flow between distant populations was rare and genetic differentiation becomes higher.

Several morphological and molecular marker techniques such as random amplified polymorphic DNA (RAPD), inter simple sequence repeats (ISSR), amplified fragment length polymorphism (AFLP), simple sequence repeat (SSR), expressed sequence-tag-derived simple sequence repeat (EST-SSR), sequence-related amplified polymorphism (SRAP), restriction fragment length polymorphism (RFLP), and interretrotransposon amplified polymorphism (IRAP) have been routinely used for genetic diversity study, population structure analysis, and characterization of bamboo germplasm [2, 40-49]. But so far, there is no study report on the molecular genetic diversity of $O$. abyssinica. Hence, as the first step in the development of genomic tools and resources that could contribute to the development of strategies for effective conservation and sustainable utilization of this bamboo for ecological and economic gains by better understanding the genetic diversity profile at the species and population level, we examined and assessed thirteen O. abyssinica populations using three chloroplast gene sequences. These molecular markers have been successfully utilized for assessing the genetic diversity and revealed a remarkable molecular genetic diversity among the $O$. abyssinica populations. 
TABLE 6: Effects of gene flow and genetic differentiation on O. abyssinica.

\begin{tabular}{|c|c|c|c|c|}
\hline \multirow{2}{*}{ Population comparison } & \multicolumn{2}{|c|}{ Genetic differentiation } & \multicolumn{2}{|c|}{ Gene flow } \\
\hline & Ks & Kxy & Gamma St & Fst \\
\hline Assosa Zone vs. Kemash Zone & 16.6 & 36.0 & 0.560 & 0.532 \\
\hline Assosa Zone vs. Metekel Zone & 36.5 & 51.5 & 0.339 & 0.341 \\
\hline Assosa Zone vs. Oromia & 15.8 & 23.0 & 0.611 & 0.606 \\
\hline Assosa Zone vs. distant pop. & 18.6 & 40.2 & 0.347 & 0.159 \\
\hline Kemash Zone vs. Metekel Zone & 40.8 & 40.5 & 0.201 & 0.134 \\
\hline Kemash Zone vs. Oromia & 17.0 & 19.2 & 0.602 & 0.503 \\
\hline Kemash Zone vs. distant pop. & 20.5 & 38.7 & 0.582 & 0.471 \\
\hline Metekel Zone vs. Oromia & 40.1 & 34.9 & 0.281 & 0.272 \\
\hline Metekel Zone vs. distant pop. & 42.4 & 51.6 & 0.149 & 0.023 \\
\hline Oromia vs. distant pop. & 19.5 & 39.2 & 0.387 & 0.117 \\
\hline
\end{tabular}

Note. Ks denotes nucleotide-sequence-based statistics, Kxy: average number of nucleotide differences between population 1 and population 2, GammaSt: genetic differences among population, and Fst: average level of gene flow.

As the evolutionary rates of cpDNA are highly conserved with structural changes and nucleotide substitution [50], cpDNA regions that are coding ( $m a t K$ and $n d h F 3^{\prime}$ end) and noncoding ( $r p s 16)$ genes were used to examine genetic diversities, population structure, and gene flow analysis of O. abyssinica. The effectiveness of cpDNA regions for genetic diversity and phylogenetics studies are well approved and tested in many plants including temperate woody bamboos [16] and paleotropical woody bamboos (Poaceae: Bambusoideae: Bambuseae) [17], level phylogenetics relationships within the bamboos [51], for evaluating plant phylogeny at low taxonomic levels and for DNA barcoding [52], and for phylogenetic relationships among the one-flowered, determinate genera of Bambuseae [53].

Populations of O. abyssinica collected in Ethiopia show clear diversity based on their geographic location. Oumer et al. [15] also found the same result. This might be because the plant is indigenous to the country [9] and largely abundant with broad geographical coverage for a long time, cross-pollination nature of the flower, and the distance between sample collections sites, especially zones which were far and distant. Sample collection sites that have relatively closer distance such as Assosa, Kemash, and Oromia, showing smaller nucleotide diversity (Table 2), InDel (Table 3 and Figure 5), genetic differentiation (Table 4), and DNA divergence (Figure 6) but higher gene flow between populations (Table 4). These three sites are neighbor to each other. Assosa and Kemash zones are under the administrative system of BGR and neighbor to each other with relatively closer distance as compared to other sampling sites. Samples from Oromia are also neighbor to Kemash Zone. Thus, both geographic range and distribution of populations influence patterns of genetic diversity, differentiation, and gene flow of O. abyssinica. Indeed, cross pollination may have contributed to increasing the heterogeneity of bamboo seedlings [54]. This result is more in line with the study on African tropical forest refugia using chloroplast and nuclear DNA phylogeography [55], classification of the Chloridoideae (Poaceae) based on multigene phylogenetic trees [56], Chinese Cherry revealed by chloroplast DNA trnQ-rps16 intergenic spacer [57], natural populations of Oxalis laciniata from Patagonia Argentina using ISSR and cpDNA-based markers [58], wild soybean evaluated by chloroplast and nuclear gene sequences from 44 Chinese, four Japanese and five Korean populations [59], and endangered basal angiosperm Brasenia schreberi (Cabombaceae) in China using microsatellites [60].

Network analysis shows that haplotypes 8 and 2 (both from Assosa Zone) are the root of O. abyssinica and others diverge from this zone. In Amharic Ambesa Chacka (meaning lion's forest because of high abundance of lions in the forest) was one of the sample collection sites from Assosa Zone of Bambasi district. Years ago, the area was known for its wide and dense lowland bamboo coverage. But now, due to poor protection and human's effect on the forest, even bamboos are at risk and vulnerable to extinction.

\section{Conclusions}

Based on the results retrieved, populations of O. abyssinica collected in Ethiopia show clear diversity based on their geographic location. Metekel Zone found the most diverse population, and thus, government sectors and other stakeholders recommended focusing on conservation of lowland bamboo of Metekel Zone. Assosa Zone has found the source of evolution of $O$. abyssinica, and Gambella population shows a difference from other $O$. abyssinica populations found in Ethiopia. The current study was performed only by few chloroplast coding and noncoding genes; thus, additional coding, noncoding, and spacer chloroplast, mitochondrial, and nuclear-gene-based study on Ethiopian lowland bamboo (O. abyssinica) might give additional information on the population genetic diversity, structure, and gene flow.

\section{Data Availability}

The cpDNA sequences from the current study are available from the corresponding author upon request. GenBank accession numbers for each cpDNA genes are provided in Table 3.

\section{Conflicts of Interest}

The authors declare that they have no conflicts of interest. 


\section{Acknowledgments}

The authors would like to thank the regional and district level natural resource experts for their contribution to the collection of samples from naturally grown bamboos. The authors wou also like to thank Addis Ababa University, Assosa University, and CE-EFRC for providing them with chemicals and with vehicle for collecting samples across the country under what were often difficult conditions and The World Academy of Science (TWAS)_COMSATS University Islamabad (CUI) fellowships, Islamabad, Pakistan, for facilitating laboratory works. This research was financially supported by the (1) International Network for Bamboo and Rattan (INBAR): International Fund for Agricultural Development (IFAD) European Union (EU) (IFAD-EU) funded programme: South-South knowledge transfer strategies for scaling up pro-poor bamboo livelihoods, income generation and employment creation, and environmental management in Africa (Phase II) (2000000529/ 2000000979) and a capacity building competitive grant training the next generation of scientists provided by Carnegie Cooperation of New York through the Regional Universities Forum for Capacity Building in Agriculture (RUFORUM) (RU/2016/Carnegie/DFS/007).

\section{References}

[1] S. Canavan, D. M. Richardson, V. Visser, J. J. Le Roux, M. S. Vorontsova, and J. R. Wilson, "The global distribution of bamboos: assessing correlates of introduction and invasion," AoB Plants, vol. 9, no. 1, 2017.

[2] S. Li, M. Ramakrishnan, K. K. Vinod, R. Kalendar, K. Yrjälä, and M. Zhou, "Development and deployment of highthroughput retrotransposon-based markers reveal genetic diversity and population structure of Asian bamboo," Forests, vol. 11 , no. 1 , p. 31,2020

[3] G. Tao, Y. Fu, and M. Zhou, "Advances in studies on molecular mechanisms of rapid growth of bamboo species," Journal of Agricultural Biotechnology, vol. 26, no. 5, pp. 871887, 2018.

[4] D. O. Ekhuemelo, E. T. Tembe, and F. A. Ugwueze, "Bamboo: a potential alternative to wood and wood products," South Asian Journal of Biological Research, vol. 1, no. 1, pp. 9-2, 2018.

[5] Bamboo Phylogenetic Group (BPG), “An updated tribal and subtribal classification of the bamboos (Poaceae: Bambusoideae)," Bamboo Science \& Culture, vol. 24, pp. 1-10, 2012.

[6] Grass Phylogeny Working Group II, "New grass phylogeny resolves deep evolutionary relationships and discovers $\mathrm{C}_{4}$ origins," New Phytologist, vol. 193, no. 2, pp. 304-312, 2012.

[7] M. Lobovikov, S. Paudel, M. Piazza, H. Ren, and J. Wu, "World bamboo resources. A thematic study prepared in the framework of the," Global Forest Resources Assessment, vol. 73, 2005.

[8] Y. Zhao, D. Feng, D. Jayaraman et al., "Bamboo mapping of Ethiopia, Kenya and Uganda for the year 2016 using multitemporal landsat imagery," International Journal of Applied Earth Observation and Geoinformation, vol. 66, pp. 116-125, 2018.

[9] E. Kassahun, "The indigenous bamboo forests of Ethiopia: an overview," AMBIO: A Journal of the Human Environment, vol. 29, no. 8, pp. 518-521, 2000.
[10] E. Kelbessa, T. Bekele, A. Gebrehiwot, and G. Hadera, A SocioEconomic Case Study of the Bamboo Sector in Ethiopia: An Analysis of the Production to-Consumption System, INBAR, Beijing, China, 2000.

[11] E. Kassahun, L. Christersson, S. Ledin, and M. Weih, "Bamboo as bioresource in Ethiopia: managements and strategy to improve seedling performance (Oxytenanthera abyssinica)," Bioresource Technology, vol. 88, pp. 33-39, 2003.

[12] Y. Mulatu, A. Alemayehu, and Z. Tadesse, Bamboo Species Introduced in Ethiopia, Ethiopian Environment and Forest Research Institute (EEFRI), Addis Ababa, 2016.

[13] N. Bystriakova, V. Kapos, I. Lysenko, and C. Stapleton, "Distribution and conservation and status of forest bamboo biodiversity in the Asia-Pacific region," Biodiversity and Conservation, vol. 12, pp. 1833-1841, 2003.

[14] W. Abtew and S. B. Dessu, "Grand Ethiopian renaissance dam site importance," in The Grand Ethiopian Renaissance Dam on the Blue Nile, pp. 63-77, Springer, Cham, Switzerland, 2019.

[15] O. A. Oumer, K. Dagne, T. Feyissa, K. Tesfaye, J. Durai, and M. Z. Hyder, "Genetic diversity, population structure, and gene flow analysis of lowland bamboo [Oxytenanthera abyssinica (A. Rich.) Munro] in Ethiopia," Ecology and Evolution, vol. 10, no. 20, pp. 11217-11236, 2020.

[16] L. R. Attigala, "Phylogenetics, systematics and evolution of the temperate woody bamboos with an emphasis on the Kuruna clade," Doctoral dissertation, Iowa State University, Ames, IA, USA, 2015.

[17] H. Chokthaweepanich, "Phylogenetics and Evolution of the Paleotropical Woody Bamboos (Poaceae: Bambusoideae: Bambuseae)," Doctoral dissertation, Iowa State University, Ames, IA, USA, 2014.

[18] K. Katoh and D. M. Standley, "MAFFT multiple sequence alignment software version 7: improvements in performance and usability," Molecular Biology and Evolution, vol. 30, no. 4, pp. 772-780, 2013.

[19] S. Kumar, G. Stecher, M. Li, C. Knyaz, and K. Tamura, "MEGA X: molecular evolutionary genetics analysis across computing platforms," Molecular Biology and Evolution, vol. 35, no. 6, pp. 1547-1549, 2018.

[20] K. Tamura and M. Nei, "Estimation of the number of nucleotide substitutions in the control region of mitochondrial DNA in humans and chimpanzees," Molecular Biology and Evolution, vol. 10, no. 3, pp. 512-526, 1993.

[21] N. Saitou and M. Nei, "The neighbor-joining method: a new method for reconstructing phylogenetic trees," Molecular Biology and Evolution, vol. 4, no. 4, pp. 406-425, 1987.

[22] J. Felsenstein, "Confidence limits on phylogenies: an approach using the bootstrap," Evolution, vol. 39, no. 4, pp. 783-791, 1985.

[23] W. Amos and J. Harwood, "Factors affecting levels of genetic diversity in natural populations," Philosophical Transactions of the Royal Society of London. Series B: Biological Sciences, vol. 353, no. 1366, pp. 177-186, 1998.

[24] S. U. Pauls, C. Nowak, M. Bálint, and M. Pfenninger, "The impact of global climate change on genetic diversity within populations and species," Molecular Ecology, vol. 22, no. 4, pp. 925-946, 2013.

[25] M. Wellenreuther, R. A. Sánchez-Guillén, A. Cordero-Rivera, E. I. Svensson, and B. Hansson, "Environmental and climatic determinants of molecular diversity and genetic population structure in a coenagrionid damselfly," PLoS One, vol. 6, no. 6, Article ID e20440, 2011.

[26] B. A. Schaal, D. A. Hayworth, K. M. Olsen, J. T. Rauscher, and W. A. Smith, "Phylogeographic studies in plants: problems 
and prospects," Molecular Ecology, vol. 7, no. 4, pp. 465-474, 1998.

[27] S. M. Moghaddam, Q. Song, S. Mamidi et al., "Developing market class specific InDel markers from next generation sequence data in Phaseolus vulgaris L." Frontiers in Plant Science, vol. 5, p. 185, 2014.

[28] M. Garcia-Diaz and T. A. Kunkel, "Mechanism of a genetic glissando: structural biology of indel mutations," Trends in Biochemical Sciences, vol. 31, no. 4, pp. 206-214, 2006.

[29] C. E. Pearson, K. N. Edamura, and J. D. Cleary, "Repeat instability: mechanisms of dynamic mutations," Nature Reviews Genetics, vol. 6, no. 10, pp. 729-742, 2005.

[30] T. T. Hu, P. Pattyn, E. G. Bakker et al., "The Arabidopsis lyrata genome sequence and the basis of rapid genome size change," Nature Genetics, vol. 43, no. 5, pp. 476-481, 2011.

[31] T. Wang, H. T. Li, H. Zhu et al., "Comparative analyses of genetic variation in a tomato (Solanum lycopersicum L.) germplasm collection with single nucleotide polymorphism and insertion-deletion markers," Russian Journal of Genetics, vol. 55, no. 2, pp. 204-211, 2019.

[32] J. Yang, Y. Wang, H. Shen, and W. Yang, "In silico identification and experimental validation of insertion-deletion polymorphisms in tomato genome," DNA Research, vol. 21, no. 4, pp. 429-438, 2014.

[33] Y. Lü, X. Cui, R. Li et al., "Development of genome-wide insertion/deletion markers in rice based on graphic pipeline platform," Journal of Integrative Plant Biology, vol. 57, no. 11, pp. 980-991, 2015.

[34] S. Das, H. D. Upadhyaya, R. Srivastava et al., "Genome-wide insertion-deletion (InDel) marker discovery and genotyping for genomics-assisted breeding applications in chickpea," DNA Research, vol. 22, no. 5, pp. 377-386, 2015.

[35] M.-b. Zhou, J.-j. Wu, M. Ramakrishnan, X.-w. Meng, and K. K. Vinod, "Prospects for the study of genetic variation among Moso bamboo wild-type and variants through genome resequencing," Trees, vol. 33, no. 2, pp. 371-381, 2019.

[36] Y. Song, Y. Chen, J. Lv, J. Xu, S. Zhu, and M. Li, "Comparative chloroplast genomes of sorghum species: sequence divergence and phylogenetic relationships," BioMed Research International, vol. 2019, Article ID 5046958, 11 pages, 2019.

[37] J. Park, Y. Suh, and S. Kim, "A complete chloroplast genome sequence of Gastrodia elata (Orchidaceae) represents high sequence variation in the species," Mitochondrial DNA Part B, vol. 5, no. 1, pp. 517-519, 2020.

[38] Y. Voichek and D. Weigel, "Identifying genetic variants underlying phenotypic variation in plants without complete genomes," Nature Genetics, vol. 52, no. 5, pp. 534-540, 2020.

[39] R. J. Britten, L. Rowen, J. Williams, and R. A. Cameron, "Majority of divergence between closely related DNA samples is due to indels," Proceedings of the National Academy of Sciences, vol. 100, no. 8, pp. 4661-4665, 2003.

[40] B. Gami, B. A. Syed, and B. Patel, "Assessment of genetic diversity in bamboo accessions of India using molecular markers," International Journal of Applied Sciences and Biotechnology, vol. 3, no. 2, pp. 330-336, 2015.

[41] Grass Phylogeny Working Group, N. P. Barker, L. G. Clark et al., "Phylogeny and subfamilial classification of the grasses (Poaceae)," Annals of the Missouri Botanical Garden, vol. 88, no. 3, pp. 373-457, 2001.

[42] S. Kochhar, B. Mal, and R. G. Chaudhary, "Population aspect of the phonological behaviour of bamboo germplasm," Bamboos Current Research, pp. 51-58, KFRI, Peechi and IDRC, Singapore, 1988.
[43] A. Nag, P. Gupta, V. Sharma, A. Sood, P. S. Ahuja, and R. K. Sharma, "AFLP and RAPD based genetic diversity assessment of industrially important reed bamboo (Ochlandra travancorica Benth)," Journal of Plant Biochemistry and Biotechnology, vol. 22, no. 1, pp. 144-149, 2013.

[44] S. Nayak, G. R. Rout, and P. Das, "Evaluation of the genetic variability in bamboo using RAPD markers," Plant Soil and Environment, vol. 49, no. 1, pp. 24-28, 2003.

[45] H. Nilkanta, T. Amom, L. Tikendra, H. Rahaman, and P. Nongdam, "ISSR marker based population genetic study of Melocanna Baccifera (Roxb.) Kurz: a commercially important bamboo of Manipur, north-east India," Scientifica, vol. 2017, Article ID 3757238, 9 pages, 2017.

[46] Y. Sun, N. Xia, and C. M. A. Stapleton, "Relationships between Bambusa species (Poaceae, Bambusoideae) revealed by random amplified polymorphic DNA," Biochemical Systematics and Ecology, vol. 34, no. 5, pp. 417-423, 2006.

[47] B. Tian, H.-Q. Yang, K.-M. Wong, A.-Z. Liu, and Z.-Y. Ruan, "ISSR analysis shows low genetic diversity versus high genetic differentiation for giant bamboo, Dendrocalamus giganteus (Poaceae: Bambusoideae), in China populations," Genetic Resources and Crop Evolution, vol. 59, no. 5, pp. 901-908, 2012.

[48] H.-Q. Yang, M.-Y. An, Z.-J. Gu, and B. Tian, "Genetic diversity and differentiation of Dendrocalamus membranaceus (Poaceae: Bambusoideae), a declining bamboo species in Yunnan, China, as based on inter-simple sequence repeat (ISSR) analysis," International Journal of Molecular Sciences, vol. 13, no. 4, pp. 4446-4457, 2012.

[49] Q. Q. Ma, H. X. Song, S. Q. Zhou, W. Q. Yang, D. S. Li, and J. S. Chen, "Genetic structure in dwarf bamboo (Bashania fangiana) clonal populations with different genet ages," PLoS One, vol. 8, no. 11, pp. 575-594, Article ID e78784, 2013.

[50] M. Lavin, P. S. Herendeen, and M. F. Wojciechowski, "Evolutionary rates analysis of Leguminosae implicates a rapid diversification of lineages during the tertiary," Systematic Biology, vol. 54, no. 4, pp. 575-594, 2005.

[51] S. A. Kelchner and Bamboo Phylogeny Group, "Higher level phylogenetics relationships within the bamboos (Poaceae: Bambusoideae) based on five plastid markers," Molecular Phylogenetics and Evolution, vol. 67, no. 2, pp. 404-413, 2013.

[52] W. Dong, J. Liu, J. Yu, L. Wang, and S. Zhou, "Highly variable chloroplast markers for evaluating plant phylogeny at low taxonomic levels and for DNA barcoding," PLoS One, vol. 7, no. 4, Article ID e35071, 2012.

[53] L. Clark, S. Dransfield, J. Triplett, and G. Sánchez-Ken, "Phylogenetic relationships among the one-flowered, determinate genera of Bambuseae (Poaceae: Bambusoideae)," Aliso, vol. 23, no. 1, pp. 315-332, 2007.

[54] C. K. John and R. S. Nadgauda, "Review in vitro-induced flowering in bamboos," In Vitro Cellular \& Developmental Biology-Plant, vol. 35, no. 4, pp. 309-315, 1999.

[55] A. J. Lowe, D. Harris, E. Dormontt, and I. K. Dawson, "Testing putative African tropical forest refugia using chloroplast and nuclear DNA phylogeography," Tropical Plant Biology, vol. 3, no. 1, pp. 50-58, 2010.

[56] P. M. Peterson, K. Romaschenko, and G. Johnson, “A classification of the Chloridoideae (Poaceae) based on multi-gene phylogenetic trees," Molecular Phylogenetics and Evolution, vol. 55, no. 2, pp. 580-598, 2010.

[57] T. Chen, X.-R. Wang, H.-R. Tang, Q. Chen, X.-J. Huang, and J. Chen, "Genetic diversity and population structure of Chinese cherry revealed by chloroplast DNA trnQ-rps16 
intergenic spacers variation," Genetic Resources and Crop Evolution, vol. 60, no. 6, pp. 1859-1871, 2013.

[58] A. López and M. G. Bonasora, "Phylogeography, genetic diversity and population structure in a Patagonian endemic plant," Aob Plants, vol. 9, no. 3, Article ID plx017, 2017.

[59] Y. Wang, F. Ghouri, M. Q. Shahid, M. Naeem, and F. S. Baloch, "The genetic diversity and population structure of wild soybean evaluated by chloroplast and nuclear gene sequences," Biochemical Systematics and Ecology, vol. 71, pp. 170-178, 2017.

[60] Z.-Z. Li, A. W. Gichira, Q.-F. Wang, and J.-M. Chen, "Genetic diversity and population structure of the endangered basal angiosperm Brasenia schreberi (Cabombaceae) in China," PeerJ, vol. 6, Article ID e5296, 2018. 